\title{
GENOTYPIC VARIABILITY OF PEANUT LINES IN RESPONSE TO WATER STRESS, BASED ON BIOCHEMICAL DESCRIPTORS ${ }^{1}$
}

\author{
GERCKSON MACIEL RODRIGUES ALVES ${ }^{2}$, JACQUELINE WANESSA DE LIMA PEREIRA ${ }^{3}$, LUCAS NUNES DA \\ LUZ $^{4}$, LIZIANE MARIA DE LIMA ${ }^{5}$, ROSEANE CAVALCANTI DOS SANTOS ${ }^{5 *}$
}

\begin{abstract}
Seven biochemical descriptors were used to estimate the genotypic variability of peanut in response to moderate water stress. Six genotypes, constituted by four lines and two cultivars, were grown in pots, each containing two plants. At 15 days after emergence (DAE), the treatment differentiation was carried out: Control-plants maintained with daily watering, and Stress-plants submitted to water stress by complete suspension of watering for 15 days. The experimental design was completely randomized with factorial scheme $6 \times 2$ (genotype $x$ water treatments), with five replications. The biochemical variables evaluated were: catalase (CAT), ascorbate peroxidase (APX), guaiacol peroxidase (GPX), free proline, total carbohydrates, soluble proteins, and amino acids. Results obtained by biochemical analysis and estimation of genotypic variability indicated that proline is the most appropriate descriptor for selecting genotypes tolerant to water stress, which led to identification of L81V and L108V as promising lines for drought tolerance breeding program.
\end{abstract}

Keywords: Arachis hypogaea L. Antioxidative enzymes. Organic solutes. Drought tolerance.

\section{VARIABILIDADE GENOTÍPICA DE AMENDOIM EM RESPOSTA A ESTRESSE HÍDRICO BASEADA EM DESCRITORES BIOQUÍMICOS}

RESUMO - Sete descritores bioquímicos foram utilizados para estimar a variabilidade genotípica de linhagens de amendoim submetidas a estresse hídrico moderado. Seis genótipos, sendo quatro linhagens e duas cultivares, foram cultivados em vasos, cada um contendo duas plantas e mantidas em casa de vegetação. Aos 15 dias após a emergência, procedeu-se a diferenciação dos tratamentos: Controle, as plantas mantidas com rega diariamente; Estresse, as plantas submetidas à suspensão total de rega durante 15 dias. $\mathrm{O}$ delineamento experimental foi inteiramente casualizado, com esquema fatorial 6 × 2 (genótipos x tratamentos hídricos), com cinco repetições. As variáveis bioquímicas avaliadas foram: catalase (CAT), ascorbato peroxidase (APX), guaiacol peroxidase (GPX), prolina livre, carboidratos totais, proteínas solúveis e aminoácidos. Baseado nos resultados das análises bioquímicas e de estimativa da variabilidade genotípica, a prolina demonstrou ser o descritor mais adequado para seleção de genótipos tolerantes ao estresse hídrico, contribuindo para indicar as linhagens L81V e L108V como mais promissoras, para um programa de melhoramento visando tolerância à seca.

Palavras-chave: Arachis hypogaea L. Enzimas antioxidativas. Solutos orgânicos. Tolerância à seca.

\footnotetext{
*Corresponding Author

${ }^{1}$ Received for publication in 04/03/2014; accepted in 04/27/2016.

Extracted from the first author's Master's dissertation, funded by REPENSA/CAPES/CNPq.

${ }^{2}$ Department of Agricultural Science, Universidade Estadual da Paraiba, Campina Grande, PB, Brazil; jackson.uepb@hotmail.com.

${ }^{3}$ Department of Agriculture, Universidade Federal Rural de Pernambuco, Recife, PE, Brazil; jacquelinewlp@gmail.com.

${ }^{4}$ Rural Development Institute, Universidade da Integração Internacional da Lusofonia Afro-Brasileira, Redenção, CE, Brazil; lucasluz@unilab.edu.br.

${ }^{5}$ Biotechnology Laboratory, Embrapa Algodão, Campina Grande, PB, Brazil; liziane.lima@embrapa.br, roseane.santos@embrapa.br.
} 


\section{INTRODUCTION}

The physiology of adaptation of plants to environmental stresses varies greatly, depending on the genotype and its intrinsic, mechanisms in an attempt to minimize the cell damage (FAROOQ et al., 2009; MAFAKHERI et al., 2010; WASEEM et al., 2011). Among the biochemical responses, accumulation of organic solutes is one of the most significant during the plant defense response (MUNNS, 2002). In this respect, enzymes play a key role in response to injury, especially the antioxidatives, that are involved in cell protection against reactive oxygen species (ROS), and are reduced to highly unstable molecular oxygen forms, including superoxide $\left(\mathrm{O}_{2}{ }^{--}\right)$, hydrogen peroxide $\left(\mathrm{H}_{2} \mathrm{O}_{2}\right)$, hydroxyl radical $\left({ }^{\circ} \mathrm{OH}\right)$ and singlet oxygen $\left({ }^{1} \mathrm{O}_{2}\right)$ (SHARMA et al., 2012). These forms are accumulated in cell as by-products of aerobic metabolism processes and photooxidation (APEL; HIRT, 2004; KARUPPANAPANDIAN et al., 2009; PEREIRA et al., 2012). Being reactive, they alter the cell metabolism by oxidative damage to lipids, proteins and nucleic acids (AZEVEDO NETO et al., 2009; FOYER; NOCTOR, 2005).

In plants, several antioxidative enzymes are involved in cellular defense against free radicals, such as superoxide dismutase (SOD), which catalyzes dismutation of superoxide radical in $\mathrm{H}_{2} \mathrm{O}_{2}$ and $\mathrm{O}_{2}$, and also catalase (CAT) and ascorbate peroxidase (APX), which can break $\mathrm{H}_{2} \mathrm{O}_{2}$ into $\mathrm{H}_{2} \mathrm{O}$ and $\mathrm{O}_{2}$. In condition of severe stress, this regulation is lost due to increased production of free radicals, triggering a series of events, starting with the peroxidation of lipids, followed by membrane degradation and cell death (APEL; HIRT, 2004; AZEVEDO NETO et al., 2009; KARUPPANAPANDIAN et al., 2009; SANKAR et al., 2007). In order to adjust osmotically, plants retain the water potential and turgor of the adjacent cells the appropriate level, producing and accumulating organic compounds such as sugars, proline, organic acids and others (NEPOMUCENO et al., 2001; FAROOQ et al., 2009; PEREIRA et al., 2012). Proline is one of the most studied osmoregulators, due to its active involvement in cell response to environmental stresses. According to some authors, plants tolerant to physiological stresses synthesize a higher amount of proline (MAIA et al., 2007; PEREIRA et al., 2012).

In plant breeding programs focused on tolerance to abiotic stresses, the understanding of these biochemical mechanisms is critical for selection, since those procedures, based only on agronomic traits, may not reflect the actual status of the plant considering extrinsic variables associated with crop management (SANTOS et al., 2013).

Peanut (Arachis hypogaea L.), is an oleaginous crop that can adjust physiologically when it detects water stress situation (AZEVEDO NETO et al., 2009). The deepening the roots, the fast recovery of stomata opening after drought relief, and the adjustment of proline accumulation are expressive responses in tolerant plants. The stress tolerance in peanut is genotype-dependent. It is greater in $A$. hypogaea subsp. fastigiata and $A$. hypogaea subsp. vulgaris, and lower in A. hypogaea subsp. hypogaea (SANTOS; GODOY; FÁVERO, 2005).

The Identification of tolerant materials contributes broadly to selecting top genotypes for further use in breeding program. Using molecular tools to select suitable parents to generate divergent populations, based on traits associated with tolerance to semiarid region, Santos et al. (2013), generated a population from BR 1 (A. hypogaea subsp. fastigiata) and LViPE-06 (A. hypogaea subsp. hypogaea), whose descendants showed high genetic variability for various agronomic traits adopted in peanut breeding program. In the present study, the four best lines of the population generated by Santos et al. (2013) were used in order to estimate the genetic variability for drought tolerance, based on enzymatic descriptors and organic solutes.

\section{MATERIAL AND METHODS}

Six peanut genotypes, two cultivars tolerant to drought (BR 1 and Senegal 55 437) used as references, and four interespecific lines (L59V, L37V, L81V and L108V), generated by crossing from BR 1 and LViPE-06, were evaluated in this study. BR 1 is subsp. fastigiata, var. fastigiata and Senegal 55 437, subsp. fastigiata, var. vulgaris (SANTOS et al., 2013). The assay was carried out in a greenhouse at Embrapa Cotton, Campina GrandePB (07 13 '50” S; 35 52'52” W; $552 \mathrm{~m})$ in pots $(15$ L) containing substrate (Plantmax $\left.{ }^{\circledR}\right)$ supplemented with $80 \mathrm{~g}$ dolomitic limestone, $15 \mathrm{~g}$ of superphosphate and $8 \mathrm{~g}$ of potassium chloride based on the recommendation, described in Santos et al. (2006). The plants were watering daily, keeping the humidity close to field capacity, determined by gravimetric method (NOGUEIRA, 1987). The pots were weighed daily, and volume of water lost by evapotranspiration was compensated by watering. At 15 days after emergence (DAE), the treatments were differentiated as control (daily watering) and moderate stress complete suspension of watering for 15 days (water suppression during 15 days). (SANKAR et al., 2007). The experimental design was completely randomized with factorial $6 \times 2$, with and five replications. The experimental unit consisted of a pot containing two plants of each genotype. A summary of agronomic descriptors of the materials studied is shown in Table 1. 
G. M. ALVES et al.

Table 1. Summary of some agronomic descriptors of peanut genotypes.

\begin{tabular}{lccccccccc}
\hline & & & & \multicolumn{5}{c}{ Seed } \\
\cline { 7 - 10 } Genotype & Genealogy/Origin & $\begin{array}{c}\text { Cycle } \\
\text { (days) }\end{array}$ & B (DAE) & GH & Color & Shape & Size & No/pod \\
\hline Senegal 55 437 & Cultivar/Africa & $80-85$ & $20-22$ & $\mathrm{U}$ & $\mathrm{T}$ & $\mathrm{Ro}$ & $\mathrm{S}$ & 2 \\
BR 1 & Cultivar/Brazil & $85-87$ & $22-24$ & $\mathrm{U}$ & $\mathrm{R}$ & $\mathrm{Ro}$ & $\mathrm{M}$ & $3-4$ \\
L-59V & Top line/Brazil & $110-112$ & $24-26$ & $\mathrm{U}$ & $\mathrm{R}$ & $\mathrm{Ro}$ & $\mathrm{M}$ & $2-3$ \\
L-37 V & Top line/Brazil & $90-95$ & $28-30$ & $\mathrm{MU}$ & $\mathrm{R}$ & $\mathrm{Ro}$ & $\mathrm{M}$ & $2-3$ \\
L-81V & Top line/Brazil & $100-102$ & $26-28$ & $\mathrm{U}$ & $\mathrm{T}$ & $\mathrm{El}$ & $\mathrm{M}$ & 2 \\
L-108V & Top line/Brazil & $93-95$ & $25-27$ & $\mathrm{U}$ & $\mathrm{R}$ & $\mathrm{Ro}$ & $\mathrm{S}$ & $2-3$ \\
\hline
\end{tabular}

B: blooming, DAE - days after emergence; GH - growth habit: U - Upright, MU - mid-upright; Color: T - tan , R - red; Shape: Ro - rounded, El - elongated; Size: S - small, M - medium.

After 15 days of water suppression, young leaves from canopy were collected for biochemical assays, following methodology described in Nogueira and Santos (2000). The tests were carried out in Gene Expression Laboratory (UFRPE) and the measures were taken via spectrophotometry (BIOMATE 3, Thermo Scientific), with 5 repetitions.

\section{Biochemical analysis}

A crude extract $(25 \%)$ of leaves was prepared in phosphate monobasic buffer $(100 \mathrm{mM})$ and EDTA $(0.1 \mathrm{mM}, \mathrm{pH} 7.0)$, which was used to determination of organic solutes and activity of antioxidative enzymes.

Total protein concentration was determined by Bradford method (1976), the absorbance measured at $595 \mathrm{~nm}$. Amino acids were determined according to the methodology described by Yemm; Coking and Ricketts (1955), using Ninhydrin (5\%) + $\mathrm{KCN}(0.2 \mathrm{mM})$ as developer solution and read at 570 $\mathrm{nm}$. Soluble carbohydrates were determined at 490 $\mathrm{nm}$, according to Dubois et al. (1956), by adding 500 $\mu \mathrm{L}$ of phenol $(5 \%)$ and $2.5 \mathrm{ml}$ of concentrated sulfuric acid to the crude extract $(500 \mu \mathrm{L})$. Free proline was determined based on methodology from Bates (1973). The reaction, containing $1 \mathrm{ml}$ extract, 1 $\mathrm{ml}$ of ninhydrin acid, and $1 \mathrm{ml}$ of glacial acetic acid, held in a water bath at $100{ }^{\circ} \mathrm{C}$ for 1 hour, was stopped by incubation on ice, followed by addition of $2 \mathrm{~mL}$ of toluene while stirring. The less dense phase was used to estimate the concentration at 520 $\mathrm{nm}$.

For enzymatic reactions: catalase (CAT) was determined following the methodology of Junior Beers and Sizer (1952). The reaction (1.5 mL) consisted of $100 \mathrm{mM}$ phosphate monobasic buffer and $0.1 \mu \mathrm{M}$ EDTA (pH 7.0), $20 \mathrm{mM} \mathrm{H}_{2} \mathrm{O}_{2}$ and $50 \mu \mathrm{L}$ of protein extract. The activity was determined by degradation of $\mathrm{H}_{2} \mathrm{O}_{2}$ in the range of 1 minute at 240 $\mathrm{nm}$. Quantitation was performed by adopting the molar extinction coefficient $36 \mathrm{M}^{-1} \mathrm{~cm}^{-1}$. The peroxidases, ascorbate peroxidase (APX) and guaiacol peroxidase (GPX), were determined according methodologies of Nakano and Asada (1981) and Urbanek et al. (1991), respectively. APX activity was determined by oxidation of ascorbate (molar extinction coefficient $2.8 \mathrm{mM}^{-1} \mathrm{~cm}^{-1}$ of ascorbate) within 1 minute at $290 \mathrm{~nm}$. GPS was estimated by the amount of tetraguaiacol formed, using the extinction coefficient $26.6 \mathrm{mM}^{-1} \mathrm{~cm}^{-1}$.

\section{Statistical analysis}

Each analysis was performed in triplicate and means were used to statistical analises. The data were submitted to ANOVA in factorial design with two factors, using the software Genes version 2009.7.0 (CRUZ, 2006). Means were compared by Tukey test $(\mathrm{P}<0.05)$. The genetic parameters were estimated considering a fixed model. These parameters were estimated:

S2g - genetic variability; H2 - genotypic determination coefficient; and Iv - variation index (CVg/CVe).

$$
\mathrm{S}^{2} \mathrm{~g}=\frac{\mathrm{QMG}-\mathrm{QMR}}{\mathrm{r}}
$$

where $S^{2}$ : genetic variability, QMG: mean square genotype, QMR: mean square, r: replication.

$$
\mathrm{H}^{2}=\frac{\mathrm{QMG}-\mathrm{QMR}}{\mathrm{QMG}}
$$

where $\mathrm{H}^{2}$ : coefficient of determination genotypic, QMG: mean square genotype and QMR: mean square. 


$$
\begin{aligned}
& \mathrm{I}_{\mathrm{v}}=\frac{\mathrm{c}_{\mathrm{Wg}}}{\mathrm{c}_{\mathrm{ve}} \quad \text { to }} \quad \mathrm{C}_{\mathrm{vg}}=\frac{100 \sqrt{s^{2} g}}{\mathrm{~m}} \\
& \mathrm{c}_{\mathrm{ve}}=\frac{100 \sqrt{s^{2} s}}{\mathrm{~m}}
\end{aligned}
$$

and

where Iv: variation index, CVg: coefficient of genotypic variation, CVe: environmental variation coefficient, $\mathrm{S}^{2} \mathrm{~g}$ : genetic variability, $\mathrm{S}^{2} \mathrm{e}$ : environmental variability, $\mathrm{m}$ : average.

\section{RESULTS AND DISCUSSION}

Statistically significant difference was observed between genotypes for all traits $(5 \%$ probability), but not between treatments, indicating that the genotypes had predictable behavior within each treatment. There was, however, interaction effect for all solutes $(p \leq 0.05)$, which means that the genotypes responded differentially in each condition studied. The coefficient of variation ranged from $14.68 \%$ to $27.47 \%$, indicating reliability of data.

The concentrations of total protein and amino acids were similarly higher only in two lines, $43 \%$ and $66 \%$ in $\mathrm{L} 59 \mathrm{~V}$, and $24 \%$ and $77 \%$ in $\mathrm{L} 108 \mathrm{~V}$, respectively (Table 2). However, proline was significantly higher in all genotypes, notably in BR 1, Senegal 55437 and L108V, with accumulations of $4.5 \mathrm{X}, \quad 3.9 \mathrm{X}$ and 4.6X, respectively. The concentration of carbohydrates, was higher in all genotypes, excepting to L37V. The best results was obtained to BR 1, L81V and L108V at 1.4X, 1.3X and $1.3 \mathrm{X}$, respectively (Table 2 ).

Table 2. Averages of organic solutes, soluble protein, amino acid, proline, carbohydrates, analyzed in leaves of peanut

\begin{tabular}{|c|c|c|c|c|c|c|c|c|}
\hline \multirow{2}{*}{ Genotypes } & \multicolumn{2}{|c|}{$\begin{array}{c}\mathrm{PT} \\
(\mu \mathrm{g} / \mathrm{gMF})\end{array}$} & \multicolumn{2}{|c|}{$\begin{array}{c}\mathrm{AA} \\
(\mu \mathrm{mol} / \mathrm{gMF})\end{array}$} & \multicolumn{2}{|c|}{$\begin{array}{c}\text { PRO } \\
(\mu \mathrm{mol} / \mathrm{gMF})\end{array}$} & \multicolumn{2}{|c|}{$\begin{array}{c}\text { CARB } \\
(\mu \mathrm{mol} / \mathrm{gMF})\end{array}$} \\
\hline & $\mathrm{C}$ & $\mathrm{S}$ & & & $\mathrm{C}$ & $\mathrm{S}$ & $\mathrm{C}$ & $\mathrm{S}$ \\
\hline Senegal 55437 & $61.5 \mathrm{Aa}$ & $67.6 \mathrm{Aab}$ & $39.4 \mathrm{Aa}$ & $41.3 \mathrm{Ab}$ & $1.6 \mathrm{Bb}$ & $6.3 \mathrm{Aa}$ & $38.8 \mathrm{Aab}$ & $48.6 \mathrm{Bbc}$ \\
\hline BR 1 & $66.7 \mathrm{Aa}$ & $59.7 \mathrm{Ab}$ & $24.7 \mathrm{Ab}$ & $32.0 \mathrm{Ab}$ & $1.5 \mathrm{Bb}$ & $6.8 \mathrm{Aa}$ & $44.8 \mathrm{Aa}$ & $63.7 \mathrm{Ba}$ \\
\hline L59V & $52.8 \mathrm{Bab}$ & $75.8 \mathrm{Aa}$ & $43.0 \mathrm{Ba}$ & $71.3 \mathrm{Aa}$ & $2.6 \mathrm{Ba}$ & $5.3 \mathrm{Ab}$ & $43.7 \mathrm{Aa}$ & $54.5 \mathrm{Bb}$ \\
\hline L37V & $62.5 \mathrm{Aa}$ & $54.4 \mathrm{Ab}$ & 32.2 Aab & $38.6 \mathrm{Ab}$ & $1.3 \mathrm{Bbc}$ & $1.8 \mathrm{Ac}$ & $41.7 \mathrm{Aa}$ & $43.8 \mathrm{Ac}$ \\
\hline L81V & $62.8 \mathrm{Aa}$ & 66.1 Aab & 36.4 Aab & $47.2 \mathrm{Ab}$ & $0.8 \mathrm{Bc}$ & $2.0 \mathrm{Ac}$ & 39.2 Aab & $52.7 \mathrm{Bb}$ \\
\hline L108V & $47.9 \mathrm{Ab}$ & $59.5 \mathrm{Bb}$ & $29.7 \mathrm{Bb}$ & 52.6 Aab & $0.5 \mathrm{Bc}$ & $2.3 \mathrm{Ac}$ & 38.3 Aab & $51.7 \mathrm{Bb}$ \\
\hline FT & 4.24 & & & & 378.85 & & 11.24 & \\
\hline FG & 1.67 & & & & 21.2 & & 1.35 & \\
\hline FGT & 2.74 & & & & 10.14 & & 2.54 & \\
\hline CV (\%) & 14.68 & & & & 27.47 & & 19.97 & \\
\hline
\end{tabular}
genotypes submitted to 15 days of water stress.

Means followed by the same letter do not differ statistically by Tukey test $(\mathrm{p} \leq 0.05)$. Uppercase compare between water treatment (C- control, S- Stress) and lowercase among genotypes. PT- Soluble protein, AA- Soluble amino acids, PROProline, CARB- Carbohydrates. F- value obtained in the analysis of variance by F test to: treatments (FT), genotypes (FG) and interaction (FGT); CV- coefficient of variation.

The increasing of some organic solutes in plant tissues under abiotic stress is a natural process in response to changes of cell metabolism, in natural conditions (AZEVEDO NETO et al., 2009; WASEEM et al., 2011; PEREIRA et al., 2012). According to Waseem et al. (2011), to maintain the hydric balance, plants often alter their metabolism in order accumulating organic solutes, amino acids, organic acids, and ions, especially potassium. Among the organic solutes, proline is one of the most widely studied, due to differential response of plants when face both biotic or abiotic stresses (GILL et al., 2010; MAFAKHERI et al., 2010).

In peanut, a high proline accumulation is a characteristic often observed in plants facing a situation of water stress (AZEVEDO NETO et al., 2009; PEREIRA et al., 2012). The magnitude of expression depends on physiological phase of plant cycle and suration of water stress.

Pereira et al. (2012) submitted cv. Senegal 55 437 to 7 days of water suspension, from 15 dae, and found high proline accumulation in the leaves, next 
to $105 \%$. In other work, Azevedo Neto et al. (2009) submitted peanut plants to 45 days os total water suppression and detected $233 \%$ of proline accumulation in same cultivar and tissue. According to these authors, roots had proline accumulation, but were less expressive than the leaves.

Senegal 55437 (African origin) and BR 1 have been widely used as parents in Brazilian peanut breeding in order to obtain genotypes tolerant to drought and salinity, and proline accumulation has been adopted as a physiological selection criterion for drought tolerance (NOGUEIRA; SANTOS, 2000; SANTOS et al., 2010; GRACIANO et al., 2011; PEREIRA et al., 2012). Lines derived from these crosses have shown wide genetic variability for this trait BRS 151 L7 and BRS Pérola Branca cultivars, are Brazilian cultivars developed by Embrapa, and are descendants from Senegal 55437 and BR 1, respectively. Both were previously selected by using proline tests, in short and moderate water stress assays. Due to high earliness, both were recommended to semiarid environment (GOMES et al., 2007; NOGUEIRA et al., 2006; PEREIRA et al., 2012). Pereira et al. (2015) used cluster analysis to estimate the genetic divergence of peanut lines tolerant to drought, based on physiological and biochemical characters, and reported that proline was the descriptor that most contributed to distinguish the genotypes, both in leaf and root tissues.

Table 3 shows the means of antioxidative enzymes obtained from peanut genotypes after 15 days of water suppression. It was found that, under stress conditions, all genotypes showed reduction of $26 \%$ in CAT activity excepting to L59V that did not show statistical difference in treatments. Under the same conditions, GPX activity was reduced to $29 \%$, $38 \%, 64 \%$ and $39 \%$ to Senegal 55 437, BR 1, L81V and $\mathrm{L} 108 \mathrm{~V}$, respectively, while GPX was reduced to $85 \%, 28 \%, 30 \%$ and $35 \%$, to same genotypes.

Table 3. Activity of antioxidative enzymes $\left(\mu \mathrm{M} \mathrm{H}_{2} \mathrm{O}_{2} \min ^{-1} \mathrm{~g}^{-1} \mathrm{MF}\right)$ analyzed in leaves of peanut genotypes submitted to 15 days of water stress.

\begin{tabular}{|c|c|c|c|c|c|c|}
\hline \multirow{2}{*}{ Genotypes } & \multicolumn{2}{|c|}{ CAT } & \multicolumn{2}{|c|}{ GPX } & \multicolumn{2}{|c|}{ APX } \\
\hline & $\mathrm{C}$ & $\mathrm{S}$ & $\mathrm{C}$ & $\mathrm{S}$ & $\mathrm{C}$ & $\mathrm{S}$ \\
\hline Senegal 55437 & $344.07 \mathrm{Ab}$ & $222.59 \mathrm{Bbc}$ & $1.32 \mathrm{Aab}$ & $0.93 \mathrm{Bab}$ & $2.61 \mathrm{Bc}$ & $4.83 \mathrm{Aab}$ \\
\hline BR 1 & $418.89 \mathrm{Aa}$ & $298.14 \mathrm{Ba}$ & $1.25 \mathrm{Aab}$ & $0.78 \mathrm{Bb}$ & $3.21 \mathrm{Bb}$ & 4.10 Aab \\
\hline L59V & 298.89 Abc & $245.55 \mathrm{Ab}$ & $1.45 \mathrm{Aa}$ & $1.23 \mathrm{Aa}$ & $5.25 \mathrm{Aa}$ & $5.48 \mathrm{Aa}$ \\
\hline L37V & $321.48 \mathrm{Ab}$ & $254.44 \mathrm{Bb}$ & $1.25 \mathrm{Aab}$ & $1.13 \mathrm{Aa}$ & $2.67 \mathrm{Ac}$ & $3.04 \mathrm{Ab}$ \\
\hline L81V & $269.26 \mathrm{Ac}$ & $208.88 \mathrm{Bc}$ & $1.02 \mathrm{Ab}$ & $0.37 \mathrm{Bc}$ & $2.33 \mathrm{Bc}$ & $3.04 \mathrm{Ab}$ \\
\hline $108 \mathrm{~V}$ & $317.77 \mathrm{Ab}$ & $240.00 \mathrm{Bb}$ & 1.37 Aab & $0.83 \mathrm{Bab}$ & $2.29 \mathrm{Bc}$ & $3.06 \mathrm{Ab}$ \\
\hline
\end{tabular}

Means followed by the same letter do not differ statistically by Tukey test ( $\leq \leq 0.05)$. CAT: Catalase; GPX: Guaiacol Peroxidase; APX: Ascorbate Peroxidase.

CAT activity varies depending on the duration and intensity of stress. In situations of moderate water deficit, CAT activity increases, however, when stress becomes more severe, activity is reversed. Pereira et al. (2012), evaluated the CAT activity in peanut genotypes after 7 days of drought, and found increased activity both in the leaves as well as in roots in all genotypes, being more expressive in Senegal 55437 and BR 1. Sankar et al. (2007) also observed increase of CAT of $23 \%$ and $43 \%$ in peanut genotypes ICG 669476 and ICG 221, after 10 days of drought. However, with more 20 days of water stress, Azevedo Neto et al. (2009) found $52 \%$ reduction in CAT activity in cv. Senegal 55 437. Such pattern is similar to that observed in this study, where most of the genotypes showed reduced CAT activity after 15 days of drought.
APX activity increased both under conditions of moderate stress as well as severe stress (AKCAY et al., 2010; AZEVEDO NETO et al., 2009; PEREIRA et al., 2012; SANKAR et al., 2007). In the present study, the reduction in the activities of CAT and GPX may be justified because plants use other enzymatic and/or non-enzymatic components to neutralize the various ROS. Sankar et al. (2007) also used enzymatic descriptors to study the response to drought tolerance in peanut genotypes, and found an increase in certain non-enzymatic components in the stressed genotypes, such as ascorbic acid, $\alpha$ tocopherol, and reduced glutathione.

Despite the finding in this study whereby increased tolerance to stress was observed in L81V and $\mathrm{L} 108 \mathrm{~V}$, an interesting aspect was observed with L59V which did not show a significant difference between treatments. The basal activity of GPX and 
APX enzymes in L59V was higher than that in other genotypes, including the resistant cultivar Senegal 55 437, under the same condition. This suggests that, despite no difference between treatments, the production of these two enzymes in the normal condition has been sufficient to maintain the degradation of hydrogen peroxide and protect cells from the effects of oxidative stress. Hence, it can be deduced that in management conditions dependent on water, it is likely that L $59 \mathrm{~V}$ gets better fit and undergoes less phenotypic variation due to climatic condition.

Although our data showed a tend of increased organic solutes and decreased antioxidative enzimes in plants submitted to water stress, we noted that the level of activity was higher in drought tolerant genotypes: Senegal 55 437, BR 1, L81V and L108V. These latter two are descendants from BR 1 and certainly they inherited the character of drought tolerance. Munne-Bosch and Alegre (2004) and Karuppanapandian et al. (2009) reported that the relative tolerance from each genotype to water stress is reflected by intrinsic characteristics such as low peroxidation of lipids, high stability of the membrane and higher concentration of chlorophyll and carotenoids, associated with the enzymatic oxidation system.

Based on averages of each trait, we estimated the genetic variability, taking into account the two water treatments. S2g, similar to genetic variance, although estimated as fixed model, showed reasonable variation to each trait, indicating that they could be used to select promissing lines, especially if taken together or by choosing a representative for each biochemical class (Table 4). In this case, PRO and CAT would be the most suitable traits to represent the organic solutes and antioxidative enzymes, respectively, since both are known to accumulate in plant tissues in response to water stress, involving a protection mechanism against oxidative stress (MOLINARI et al., 2007; KARUPPANAPANDIAN et al., 2009).

Table 4. Estimation of genetic variance $\left(\mathrm{S}^{2} \mathrm{G}\right)$, genotypic determination coefficient $\left(\mathrm{H}^{2}\right)$, and variation index (Iv) in biochemical descriptors estimated in peanut plants subjected to 15 days of water stress.

\begin{tabular}{|c|c|c|c|c|}
\hline \multirow{2}{*}{ Traits } & \multicolumn{4}{|c|}{ Parameters } \\
\hline & Treatments & $\mathrm{S}^{2} \mathrm{~g}$ & $\mathrm{H}^{2}(\%)$ & Iv \\
\hline \multirow[t]{2}{*}{ PT } & $\mathrm{C}$ & 35.63 & 70 & 0.33 \\
\hline & S & 28.93 & 42 & \\
\hline \multirow[t]{2}{*}{ AA } & $\mathrm{C}$ & 32.02 & 78 & 0.87 \\
\hline & S & 130.92 & 68 & \\
\hline \multirow[t]{2}{*}{ PRO } & $\mathrm{C}$ & 0.47 & 87 & 1.83 \\
\hline & S & 5.05 & 94 & \\
\hline \multirow[t]{2}{*}{ CARB } & $\mathrm{C}$ & 70.57 & 73 & 0.24 \\
\hline & $\mathrm{S}$ & -14.76 & 77 & \\
\hline \multirow[t]{2}{*}{ CAT } & $\mathrm{C}$ & 1188.03 & 45 & 0.50 \\
\hline & S & -101.42 & 10 & \\
\hline \multirow[t]{2}{*}{ GPX } & $\mathrm{C}$ & 0.66 & 88 & 0.93 \\
\hline & S & 0.12 & 77 & \\
\hline \multirow[t]{2}{*}{ APX } & $\mathrm{C}$ & 0.37 & 35 & 0.42 \\
\hline & S & 0.05 & 05 & \\
\hline
\end{tabular}

PT - Soluble Protein; AA - Amino acids; PRO - Proline; CARB; Carbohydrates; CAT - Catalase; GPX- Guaiacol Peroxidase, APX- Ascorbate Peroxidase; Treatment (C- control; S- stress). 
Genotypic determination coefficient $\left(\mathrm{H}^{2}\right)$, analogous to heritability, is an indicator of heritability of the traits. For AA and PRO, this index showed high magnitude (82.15 and 95.28, respectively), indicating possibility of choosing these trais to organic solutes, and GPX and CAT, with $\mathrm{H}^{2}$ of 60.19 and 84.05, as antioxidative enzymes, respectively. These results, based on genetic parameters, are scarce in literature. Then, we suggest that this work represent a valuable guide in breeding programs for drought tolerance.

The variation index summarizes the experimental precision since it is obtained by dividing $\mathrm{CVg} / \mathrm{CVe}$ (genotypic and environmental variation coefficients). Iv values near to unit represent a larger portion of genotypic variation in relation to environmental variation. AA, PRO and GPX showed broad reliability. This information is quite valuable to lines used in this study because all are descendants of BR 1 (earliness) and LViPE-06 (high yield). The prevalence of genetic effects over the environment, as evidenced by the variation index would be a deciding factor for selection of the best genotypes, because there is a high correlation between genotype and phenotype, allowing correct identification and selection of the best progenies. In autogamous as peanuts, while advancing the generations of autofertilization, the fixation of alleles in lines helps to maintain and even increase the evaluated characteristics. Here too, the Iv is of great importance to confirm the predominance of genic effects over non-genic effects.

\section{CONCLUSIONS}

L81V and L108V both descendants from BR 1, are more tolerant to water stress and recommended for further works in peanut breeding.

Proline is a more suitable biochemical trait to assist the selection of genotypes tolerant to water stress, based on the values of genetic parameters obtained.

\section{ACKNOWLEDGEMENTS}

To Rede REPENSA/CAPES/CNPq for financial support and granting scholarships.

\section{REFERENCES}

AKCAY, U. C. et al. Drought-induced oxidative damage and antioxidant responses in peanut (Arachis hypogaea L.) seedlings. Plant Growth Regulation, Netherlands, v. 61, n. 1, p. 21-28, 2010.
APEL, K.; HIRT, H. Reactive oxygen species: Metabolism, oxidative stress and signal transduction. Annual Review of Plant Biology, Palo Alto, v. 55, p. 373-399, 2004.

AZEVEDO NETO, A. D. et al. Physiological and biochemical responses of peanut genotypes to water deficit, Journal of Plant Interactions, Dordrecht, v. 5, n. 1, p. 1-10, 2009.

BATES, L. S. Rapid determination of free proline for water-stress studies. Plant and Soil, Dordrecht, v. 39 , n. 1 , p. $205-207,1973$

BEERS JUNIOR, R. F.; SIZER, I. W. A spectrophotometric method for measuring the breakdown of hydrogen peroxidase by catalase. Journal of Biological Chemistry, Rockville Pike, v. 195, n. 2, p. 133-140, 1952.

BRADFORD, M. M. A rapid and sensitive method for the quantitation of microgram quantities of protein utilizing the principle of protein-dye binding. Analytical Biochemistry, San Diego, v. 72, n. 1-2, p. 248-254, 1976.

CRUZ, C.D. Programa Genes - Biometria. 1. ed. Viçosa, MG: Editora UFV, 2006. v. 1.382 p.

DUBOIS, M. et al. Colorimetric method for determination of sugars and related substances. Analytical Chemistry, Washington, v. 28, n. 3, p. 350-356, 1956

FAROOQ, M. et al. Plant drought stress: effects, mechanisms and management. Agronomy for Sustainable Development, Les Ulis Cedex A, v. 29, n. 1, p. $185-212,2009$.

FOYER, C. H.; NOCTOR, G. Redox homeostis and antioxidant signaling: a metabolic interface between stress perception and physiological responses. Plant Cell, Rockville, v. 17, n. 7, p. 1866-1875, 2005.

GILL, T. et al. Over-expression of Potentilla superoxide dismutase improves salt stress tolerance during germination and growth in Arabidopsis thaliana. Journal of Plant Genetic \& Transgenics, West Lafayette, v. 1, n. 1, p. 1-10, 2010.

GOMES, L. R. et al. Adaptabilidade e estabilidade fenotípica de genótipos de amendoim de porte ereto. Pesquisa Agropecuária Brasileira, Brasília, v. 42, n. 7, p. 985-989, 2007.

GRACIANO, E. S. A. et al. Crescimento e capacidade fotossintética da cultivar de amendoim BR 1 sob condições de salinidade. Revista Brasileira de Engenharia Agrícola e Ambiental, Campina Grande, v. 15, n. 8, p. 794-800, 2011. 
KARUPPANAPANDIAN, T. et al. Chromiuminduced accumulation of peroxide content, stimulation of antioxidative enzymes and lipid peroxidation in green gram 867 (Vigna radiata L. cv. Wilczek) leaves. African Journal of Biotechnology,

MAFAKHERI, A. et al. Effect of drought stress on yield, proline and chlorophyll contents in three chickpea cultivars. Australian Journal of Crop Science, Queensland, v. 4, n. 8, p. 580-585, 2010.

MAIA, P. S. P. et al. Conteúdo relativo de água, teor de prolina e carboidratos solúveis totais em folhas de duas cultivares de milho submetidas a estresse hídrico. Revista Brasileira de Biociências, Porto Alegre, v. 5, n. S2, p. 918-920, 2007.

MOLINARI, H. B. C. et al. Evaluation of the stressinducible production of proline in transgenic sugarcane (Saccharum spp.): osmotic adjustment, chlorophyll fluorescence and oxidative stress. Physiologia Plantarum, Lund, v. 130, n. 2, p. 218229, 2007.

MUNNE-BOSCH, S.; ALEGRE, L. Die and let live: leaf senescence contributes to plant survival under drought stress. Functional Plant Biology, Collingwood, v. 31, n. 3, p. 203-216, 2004.

MUNNS, R. Comparative physiology of salt and water stress. Plant, Cell and Environment, Malden, v. 25, n. 2, p. 239-250, 2002.

NAKANO, Y.; ASADA, K. Hydrogen peroxide is scavenged by ascorbate-specific peroxidases in spinach chloroplast. Plant Cell Physiology, Quioto, v. 22 , n. 5 , p. $867-880,1981$.

NEPOMUCENO, A. L. et al. Tolerância à seca em plantas: mecanismos fisiológicos e moleculares. Biotecnologia, Ciência e Desenvolvimento, Brasília, v. 4, n. 23, p. 12-18, 2001.

NOGUEIRA, R. J. M. C. Efeitos do déficit hídrico no comportamento fisiológico de quatro cultivares de cana-de-açúcar (Saccharum sp.) adubadas ou não, com nitrogênio mineral, 1987. 156 p. Dissertação (Mestrado em Botânica: Área de Concentração em Produção vegetal) - Universidade Federal de Pernambuco, Recife, 1987.

NOGUEIRA, R. J. M. C. et al. Comportamento estomático e potencial da água da folha em amendoim cv. BRS 151 L7 submetido a estresse hídrico. Revista Brasileira de Oleaginosas e Fibrosas, Campina Grande, v. 10, n. 1/2, p. 985-991, 2006. Abraka, v. 8, n. 3, p. 475-479, 2009.

NOGUEIRA, R. J. M. C.; SANTOS, R. C. Alterações físiológicas no amendoim submetido ao estresse hídrico. Revista Engenharia Agrícola, Campina Grande, v. 4, n. 1, p. 41-45, 2000.

PEREIRA, J. W. L. et al. Mudanças bioquímicas em genótipos de amendoim submetidos a déficit hídrico moderado. Revista Ciência Agronômica, Fortaleza, v. 43, n. 4, p. 766-773, 2012.

PEREIRA, J. W. L. et al. Cluster analysis to select peanut drought tolerance lines. Australian Journal of Crop Science, Queensland, v. 9, n. 11, p. 1095 1105,2015

SANKAR, C. et al. Effect of paclobutrazol on water stress amelioration through antioxidants and free radical scavenging enzymes in Arachis hypogaea L. Colloids and Surfaces B: Biointerfaces, Amsterdam, v. 60, n. 2 , p. $229-235,2007$

SANTOS, R. C.; GODOY, J. I.; FÁVERO, A. P. Melhoramento do Amendoim. In: SANTOS, R. C. (Ed.). O Agronegócio do Amendoim no Brasil. Campina Grande: Embrapa Algodão, 2005, cap. 4, p. 124-192.

SANTOS, R. C. et al. BRS Havana: nova cultivar de amendoim de pele clara. Pesquisa Agropecuária Brasileira, Brasília, v.41, p.1337-1339, 2006.

SANTOS, R. C. et al. Produtividade de linhagens avançadas de amendoim em condições de sequeiro no Nordeste brasileiro. Revista Brasileira de Engenharia Agrícola e Ambiental, Campina Grande, v. 14, n. 6, p. 589-593, 2010.

SANTOS, R. C. et al. Variabilidade de progênies F2 de amendoim geradas por meio de seleção de genitores ISSR-divergentes. Revista Ciência Agronômica, Fortaleza, v. 44, n. 3, p. 578-586, 2013.

SHARMA, P. et al. Reactive oxygen species, oxidative damage, and antioxidative defense mechanism in plants under stressful conditions. Journal of Botany, Cairo, v. 2012, n. ID 217037, p. $1-26,2012$.

URBANEK, H.; KUZNIAK-GEBAROWSKA, E.; HERKA, K. Elicitation of defense responses in bean leaves by Botrytis cinerea polygalacturonase. Acta Physiologiae Plantarum, Heidelberg, v. 13, n. 1, p. 43-50, 1991.

WASEEM, M. et al. Mechanism of drought tolerance in plant and its management through different methods. Continental Journal Agricultural Science, Akure, v. 5, n. 1, p. 10-25, 2011 . 
YEMM, E. W.; COKING, E. C.; RICKETTS, R. E.

The determination of amino-acids with ninhydrin.

Analyst, Cambridge, v. 80, n. 948, p. 209-214, 1955. 